\title{
Misleading Advertisement in Islamic Law and Consumer Law in Arab Countries
}

\author{
Ahmad Ibrahim Al Sharu ${ }^{{ }^{*}} \quad$ Fauziah Binti Mohd Noor ${ }^{2} \quad$ Rohana Binti Abdul Rahman ${ }^{3}$ \\ School of law, Universiti Utara Malaysia, Malaysia
}

\begin{abstract}
Advertising can greatly increase a company's revenue and it becomes part of company's promotion tool. Many companies invest significantly on advertising. Nonetheless, in attracting new customers, some advertising makes false promises, which is forbidden in Islam. This study highlights the notion of misleading advertisement from the Islamic perspective and from legal perspective based on the legislation in some Arab countries with special reference to Jordan. Islam allows business conducts so long that they abide by the principles of Shari'ah. Hence, misleading practices, deception, unfairness, misrepresentation, force and injustice in measurement, are prohibited. This paper attempts to identify the Islamic standpoint towards misleading advertisement, to promote truthful advertising.
\end{abstract}

Keywords: Advertising, Business, Misleading Advertisement, Islamic Perspective, Legal Perspective

DOI: $10.7176 / \mathrm{JLPG} / 105-03$

Publication date: January $31^{\text {st }} 2021$

\section{Introduction}

The expression "advertise" comes from a Latin word "advertere" which refers to "turn toward or to take note of." In essence, visual and verbal commercial messages make up an advertising with the purpose of grabbing viewer's attention and compelling the viewer to show certain response. It is nearly not possible to dodge advertising as it is ubiquitous in nature. There are various ways of advertising, however, newspapers and magazines often have more advertisements compared to other media. As providers of entertainment, radio and television present advertisements too, and advertisements also appear on Internet sites, emails, mails, subways and train stations, bus stop benches, vehicle license plates, billboards, and so forth. In short, advertising and its creative elements are to make viewers pay attention. ${ }^{1}$

\section{Misleading Advertisement from Islamic Perspective}

'Shari'ah' encompasses an Islamic law, but it should be noted that the concept of 'law' in Islam is wider than that within a legal context. This Arabic word means 'path' or 'guide' and it means all-encompassing characteristics of Islamic Law coming from two primary sources: the Holy Qur'an and the Glorious Prophetic Sunnah (Prophetic Traditions).

Other than these two sources, Islamic law is also based on secondary sources such as Ijma' and Qiyas. In addition, Islamic law in Jordan refers to the Majalla which is based on the Hanafiyah School thought. This School of thought was established in the 8th century by Abu Hanifah Al-Nu'man and it is among the four renowned Islamic Schools of thought. In protecting consumer, the Shari'ah or Islamic law bridges the gap in Jordanian legislation.

The verses of the Quran and Sunnah are ample resources of directives and regulations governing consumption in contemporary societies. In this regard, the Islamic law provides a unique insight into transactions between individuals. This insight is not meant for achieving a private interest but for establishing the public Islamic legitimate interests as a collective public interest to serve all individuals.

\section{Provisions of Quran and Sunnah}

Islamic laws prohibit the uncertain deals which are based on speculation and unclear situations, as it has been clarified before. So, in any negotiation, the Shari'ah law presents two essential principal requirements: first, if there is any kind of fraud, and second, within the mutual consent of the parties, if misleading advertisement or pressure has been exercised on the customer, then, the negotiation should be cancelled immediately. ${ }^{2}$ As such, communications based on uncertain commodities or those on commodities that are yet to exist, are greatly forbidden in Shari'ah law, as this can lead to the accumulation of wealth at the cost of others, if by chance, these commodities are muddied before the customer accepts them.

On the order hand, laws of Shari'ah boost and encourage urges trade and free trade, and also compel manufacturers to provide high quality goods and products at reasonable and fair prices without any wrong and

\footnotetext{
${ }^{1}$ Pushpa Girimaji. "Misleading advertisement and consumer". "This Monograph is published with the Financial Assistance from Department of Consumer Affairs. Ministry of Consumer Affairs, Food \& Public Distribution, Government of Indian" "institute of public administration. (2013)".

${ }^{2}$ Siddiqui, Anjum. "Financial contracts, risk and performance of Islamic banking." "Managerial finance 34”, no. 10 (2008): 680-694.
} 
untrue information. For those that abide by such laws in their business deals, God will give rewards in this world and the hereafter. This reward has been guaranteed by Prophet Mohammed [PBUH] as the Prophet had stated that God said: God loves best those who hasten to worship. ${ }^{1}$

There is no doubt that Islamic has prohibited cheating, lying, and deceit, as mentioned in many verses in the Quran and Hadith:

\subsection{Evidence from Quran}

Allah the Almighty says: "O you who have believed, do not consume one another's wealth unjustly but only [in lawful] business by mutual consent. And do not kill yourselves [or one another]. Indeed, Allah is to you ever Merciful.2" This verse clearly states that trade can only be legitimate if it was conducted with mutual consent and satisfaction without fraud or deception, otherwise the transaction is prohibited.

Furthermore, Allah the Almighty says, "O you who have believed, fulfil [all] contracts. ${ }^{3 "}$ Allah the Almighty has ordered us to honour contracts, as He also says, "Indeed, Allah orders justice and good conduct." Justice is one of the values Islam has highlighted in its moral message and teachings. Justice, honouring contracts, and cooperation in righteousness and piety are valuable moral assets that form the basis for consumer protection, because both the producer and the dealer should possess high morals.

\subsection{Evidence from Sunnah}

Many Hadiths prohibit fraud and promote consumer protection, including what was narrated on the authority of Abu Huraira. As conveyed by Abu Huraira, Prophet Muhammad (PBUH) passed by a pile of corns, and placed his hand into the pile, and found his fingers moistened. The Prophet then said to the owner of the corns: What is this? The owner replied: Messenger of Allah, these have been drenched by rainfall. He (the Holy Prophet) remarked: Why did you not place this (the drenched part of the heap) over other eatables so that the people could see it? He who deceives is not of me (is not my follower). ${ }^{5}$

Another evidence can be found in the narration of Wa'lah who said that the Messenger of Allah (PBUH) said: "No one may sell anything before discloses everything he knows about the goods and hide nothing, ${ }^{6 "}$ This Hadith clearly states that the dealer must expose the defects of what he's selling to the buyer and that any act of concealment is considered cheating.

The Hadith, which was narrated by Uqbah bin Amer, also prohibits fraud in transactions in general: "The Messenger of Allah (P.B.U.H), said: Muslims are brothers, and no Muslim may sell his brother a defected item without disclosing this defect to him."

The main function of an advertisement is to carefully, honestly, and measurably describe an item for consumers, and state its benefits and characteristics with high credibly away from the methods of influence, seduction, lies, and deception. This strategy provides the consumer with the required freedom to choose. ${ }^{8}$

\section{Ijma' and Qiyas}

Anthropological intellectual is practically applicable under Islamic law because of a method of investigation called fiqh, and this must be interpreted in English as jurisprudence. Fiqh is settled over jurists' planned energies to comprehend and spread over moralities and directions placed dejected in the heavenly foundations (the Qur'an and the Sunnah). Expressed another way, fiqh quotes and articulates exhaustive verdicts which are specified in blissful sources. This procedure is exposed to an extremely articulated provisions or approaches sketched in the Discipline of Moralities of Islamic Jurisprudence ${ }^{9}$. It is referred as Usul al-fiqh in Arabic.

Fiqh is an extremely articulated discipline and therefore only a few have sound knowledge of it such as professionals in the Qur'an and Sunnah. The Qur'an can train perceptive and this perceptive is named ijtihad in Arabic. Ijtihad in Islam is an integral aspect. Within the common fiqh, Muslims jurists are obliged to observe any of the two approaches when forming an Ijtihad such as inferring a report after the topmost texts. ${ }^{10}$

Originally, Muslim scholars can rely on Ijma' which refers to "a contract of a cluster (Jama'ah) on a firm

\footnotetext{
${ }^{1}$ Al-Albani, M. Selselat Al ahadeith Al sahiha, 4th edition, Part 3, Al-Maktib Alislami. Hadith No. 1113. (1985).

${ }^{2}$ An-Nisa', Ayah (29).

${ }^{3}$ Al-Ma'edah, Ayah (1)

${ }^{4}$ An-Nahl, Ayah (90)

${ }^{5}$ Sahih Muslim, Book of Faith, Chapter: The Saying of the prophet (saws): "Whoever deceives us is not one of us." Hadith no. 102, "Dar AlKutub al-Ilmyah", Beirut, (2001).

${ }^{6}$ Al-Shawkani, Ali Muhammad "Nabeel al Awtar Muntaqa al-Akhbar min Ahadeeth Saeed Al-Akhbar”, Dar al-Jameel, Beirut, P5, (1973).

${ }^{7}$ Ibid.

${ }^{8}$ Al-Salaheen, Abdul Majeed "Commercial Advertisements: Concept and Regulations in Islamic Fiqh", "Sharia and Law Journal", Vol 21,(2004).(In Arabic)

${ }^{9}$ Zahraa, Mahdi. "Unique Islamic law methodology and the validity of modern legal and social science research methods for Islamic research." "Arab law quarterly 18, no. 3 (2003): 215-249".

${ }^{10}$ Alzaagy, Abdulrahman A. "Electronic Contract: A Study of Its Application in the Light of Islamic Law with Particular Reference to Saudi Arabia Case." "PhD diss., University of Wales, Aberystwyth”, (2009).
} 
query by exploitation or by desertion." It is based on the utterance of Prophet Mohammad: "my people do not encounter upon mistake." Notably, compromise cannot be professed as a distinct rule, but must be grounded upon indication from either the Sunnah or the Qur'an. Also, the consent cannot be constructed in a void, but from a genuine clarification of the key foundations.

Additionally, Muslim scholars can count on the Analogy in the course of assembling the Ijtihad, or in Arabic term, Qiyas. Contrasting to the accord techniques, equivalence can be founded only on a verdict of an individual. Qiyas is well-defined as "founding the applicability of a governing in single situation to added situation on the estates of their resemblance, related to the characteristic on which the presiding is founded." ${ }^{2}$ Such distinct intellectual assumed by Qiyas and Ijma' produces what is named today "Islamic seminaries of thought." Different Islamic zones practices different perceptive, and accordingly, there are various seminaries of thought. Such differences have been attributed to the detachments among diverse zones, customs and principles of the Islamic world.

Within the context of Jordan, the Jordan Civil Law 1976(JCL 1976) which is a codified legal framework influenced by the civil law system is mainly grounded upon the Majalla. This framework is in line with the Shari'ah. In Jordan, the Islamic jurisprudence 'fiqh' is the second source of legal provision. It also becomes an alternative solution if a given case cannot be resolved with JCL 1976.

Other enactments are also bound by Majalla. In other words, Jordanian legislation is heavily influenced by the Islamic governance system, ${ }^{3}$ and it can be viewed as an Islamic oriented approach. ${ }^{4}$ Majalla is grounded upon the Hanafi School of thought, a well-known Islamic school of thought, founded by Abu Hanifah Al-Nu'man during the 8th century AC. As such, s the JCL 1976 is to be understood and construed according to the Islamic jurisprudence, ${ }^{5}$ and the likelihood of closing contracts and scrutinizing consumer protection scope under the Shari'ah.

The Majalla does not directly address consumer protection issue, but it offers general principles for contractors to understand how a valid contract should be closed. ${ }^{6}$ Hence, the Majalla has no detailed rules on information requirements, for example, but generally states that the sold commodities "must be known to the purchaser."7

Another example is in the case of misrepresentation, whereby the Majalla provides the following: If a given property sold by vendor is to have certain necessary quality but the said quality does not exist, buyer can choose to either accept or cancel the sale for full price. An example is as follows:

1. If a sold cow is claimed as producing milk but otherwise, purchaser acquires an option;

2. If a stone sold at night time is claimed as a red ruby but is in fact a yellow ruby, the purchaser acquires an option. ${ }^{8}$

In making an item known to a prospective purchaser, two methods can be used. For tangible items, they can be simply shown to the purchaser during sale meeting, and in this situation, seller is not obliged to give any description, for instance, the items' colour, dimension, weight, quantity, and quality. ${ }^{9}$ In other words, in this situation, purchaser can physically view the item before making a transactional decision. ${ }^{10}$

Accordingly, based on the Majalla "in the e-commerce arena leave uncertainty for consumers where, by analogy, it requires only that a picture of the product, rather than a description, be provided to the consumer. Secondly, the product can be known by mentioning the distinguishing characteristics if the subject matter of the contract was not presented at the time of the sale." Also, in making known the distinguishing characteristics of the product, seller can just inform the purchaser about the product's quantity, measurements and species. ${ }^{11}$

\section{Shari'ah Regulations for Commercials}

There are a number of Shari'ah regulations that every advertisement process should adhere to - from the

${ }^{1}$ Asherman, Jeanne. "Doing Business in Saudi Arabia: The Contemporary Application of Islamic Law." "The International Lawyer",vol. 16, p. 321. (1982)

${ }^{2}$ Alzaagy, Abdulrahman A. "Electronic Contract: A Study of Its Application in the Light of Islamic Law with Particular Reference to Saudi Arabia Case". "PhD diss., University of Wales, Aberystwyth, (2009)".

${ }^{3}$ Hayajneh, Abdelnaser Zeyad. "Vanishing Borders: Can Human Rights be a subject of Private Law? Exploring Human Rights under Jordanian Civil Law." “European Journal of Social Sciences” (2011).

${ }^{4}$ Hayajneh, Abdelnaser Zeyad. "Legal Surgery: The Need to Review Jordanian Civil Law.", , British Journal of Humanities and Social Sciences " (2012).

${ }^{5}$ JCL 1976, s 3

${ }^{6}$ Alhusban, Ahmad. "The importance of consumer protection for the development of electronic commerce: the need for reform in Jordan." PhD diss., Doctoral dissertation, University of Portsmouth, (2014).

${ }^{7}$ Majalla, s 200. Al-Majallah al-Ahkam al-Adaliyyah (The Majelle) - the Civil Law of the Ottoman Empire (Hanafi). Available at: http://www.global-islamic-finance.com/2009/07/al-majallah-al-ahkam-al-adaliyyah.html\#ixzz575wer3Rt (Accessed on July 2016).

${ }^{8}$ Majalla, s 310. Al-Majallah al-Ahkam al-Adaliyyah (The Majelle) - the Civil Law of the Ottoman Empire (Hanafi).Available at:

http://www.global-islamic-finance.com/2009/07/al-majallah-al-ahkam-al-adaliyyah.html\#ixzz575wer3Rt. (Accessed on July 2016).

${ }_{9}^{9}$ Majalla, s 202.

${ }^{10}$ Haider, Ali. "The Explanation Ottoman Courts Manual”. “Dar Ala'am Alkotb, Beirut, 1st, (2003)”. 178 (in Arabic).

${ }^{11}$ Ibid 
advertiser's side - in order to be permissible in terms of legitimacy. These regulations are derived from the Quran and the Sunnah. Every advertiser should be honest and avoid deceit and fraud, for his ads to be permissible. ${ }^{1}$

\subsection{Honesty}

Honesty is the mainstay of all transactions, as Prophet Muhammad (PBUH) had said: "Both parties in a business transaction have the right to annul it so long as they have not separated; and if they speak the truth and make everything clear they will be blessed in their transaction; but if they tell a lie and conceal anything the blessing on their transaction will be blotted out." 2

The best way to demonstrate the importance of honesty in transactions is by stating the great status of the honest trader in the Day of Judgment, as indicated by the words of Prophet Muhammad (PBUH): "The trustworthy, honest Muslim merchant will be with the martyrs on the Day of Resurrection." 3

Any commercial advertising must be based on honesty, since it is basically an introduction to a commercial dealing. The advertiser must be keen to display honesty and objectivity in his advertisements by disclosing all the positive and negative traits of his goods/service/institution. ${ }^{4}$

Adhering to honesty can spare commercial advertising the criticism directed to the advertisements, which claims that marketing advertisements mislead the public, proved false information, and exaggerate about the advertised goods, service, or institution, leaving a wrong impression about the item, service, or institution. ${ }^{5}$ Examples of commercial advertising that is dishonest are as illustrated below: ${ }^{6}$

1. An announcement that describes a product or service with advantages and characteristics that are nonexistent, like a biscuit factory claiming its products are free of preservatives while the truth is otherwise.

2. An advertisement that uses absolute superlative claims that are inaccurate, since it's difficult to verify its veracity. $^{7}$

3. An advertisement that promises the consumer positive outcomes after using the advertised product, while none actually exists, e.g., a cell phones shop announcing that a certain brand of mobile phones can make the consumer more masculine. ${ }^{8}$

\subsection{Avoiding Fraud and Deception}

Business transactions in Islam, which include commercial advertisement, are based on advice and clarity. Prophet Muhammad (PBUH) said: "Al-Din is a name of sincerity and well wishing. Upon this we said: For whom? He replied: For Allah, His Book, His Messenger, and for the leaders and the general Muslims." 9 Therefore, the advertiser should avoid fraud and deception in his advertisements, like claiming a certain product or service has an advantage, where none exists, or advertising an item and making it more appealing on the television, internet, or newspapers by using technology. ${ }^{10}$

Based on the above, any commercial that involves fraud or deception is considered prohibited under Islamic law, since Allah the Almighty says, " O you who have believed, do not consume one another's wealth unjustly but only [in lawful] business by mutual consent. And do not kill yourselves [or one another]. Indeed, Allah is to you ever Merciful. ${ }^{11 "}$

This verse clearly states that Allah the Almighty has specified that mutual consent and satisfaction are a condition to legalize earning money through trade, and there is no doubt that a consumer who buys an adulterated or misleading product, will not be satisfied. In this situation, the transaction has included fraud, deception, and falsehood, and is rendered prohibited.

\footnotetext{
${ }^{1}$ Al-Manaseer, Ali Abdul Kareem Muhammad, "Commercial Advertisements: Concept and Ruling in Islamic Fiqh”, "Dissertation, School of Legal Studies, Jordan University", (2007).

${ }^{2}$ Sahih Muslim, Book of Faith, Chapter: The Saying of the prophet (saws): "Whoever deceives us is not one of us.", Hadith no. 102, "Dar AlKutub al-Ilmyah, Beirut”, (2001).

${ }^{3}$ In Majah," Book of Business Transactions", al-Maktab al-Islamy, Beirut, Hadith no. 2139, (1986)

${ }^{4}$ Al-Manaseer, Ali Abdul Kareem Muhammad, "Commercial Advertisements: Concept and Ruling in Islamic Fiqh", Dissertation, School of Legal Studies, Jordan University”, (2007).

${ }^{5}$ Ahmad Shakir, “Advertisment”, Dar Wael, Amman - Jordan,( 2003). In Arabic

${ }^{6}$ Al-Manaseer, Ali Abdul Kareem Muhammad, "Commercial Advertisements: Concept and Ruling in Islamic Fiqh", "Dissertation, School of Legal Studies, Jordan University”, (2007).

${ }_{7}$ Al-Salaheen, Abdul Majeed "Commercial Advertisements: Concept and Regulations in Islamic Fiqh", "Sharia and Law Journal”, Vol 21, (2004). (In Arabic)

${ }^{8}$ Ibid

${ }^{9}$ Sahih Muslim, Book of Faith, Chapter: The Saying of the prophet (saws): "Whoever deceives us is not one of us."," Hadith" no. 102," Dar Al-Kutub al-Ilmyah, Beirut", (2001).

${ }^{10}$ Al-Salaheen, Abdul Majeed "Commercial Advertisements: Concept and Regulations in Islamic Fiqh", "Sharia and Law Journal", Vol 21, (2004). (In Arabic).

${ }^{11}$ Al-Manaseer, Ali Abdul Kareem Muhammad, "Commercial Advertisements: Concept and Ruling in Islamic Fiqh"," Dissertation, School of Legal Studies, Jordan University”, (2007).
} 


\section{Arab Countries}

Within the Arab domain, customer safety is an attractive zone for researchers since it has been ignored by the law makers. Somehow, the emphasis of academic script has been limited to the progress of customer defence regulation in developed states and the universal strategies of Islamic law in the customer defence arena, as there is no sole organised customer guard law in the Arab zone.1 Interestingly, advertisements in the Arab world was worth \$4.6B USD in 2009 conferring to a description presented by Dubai Press Club. ${ }^{2}$

Many Arab countries have recently showed real attention towards consumer protection by the issuance of special laws including The Egyptian Law, consumer protection No. 67 of 2006, consumer protection Syrian Law No. 14 of 2015, as well as federal Law of UAE No. 24 of 2006 on the protection of the consumer. ${ }^{3}$

JCL 1976, section $94 / 2$ stipulates that: "the publication and announcement and the statement of prices being handled by another statement and all related offer or requests addressed to the public or individuals is not considered when in doubt, but an invitation to negotiate." ${ }^{\prime 4}$ Accordingly, must be displayed clearly, it denies doubt the intention of the source and its sanctity as well as an intention to negotiate. ${ }^{5}$

Section 26 in the UAE Law consumer protection states that it is prohibited for any person to advertise any service or good to the consumer using a misleading or deceitful way. There are a few elements in the Draft Law 2013 and UAE Consumer Protection Law, showing the need to amend and re-examine those laws in order to ensure civil protection from misleading commercials for consumers. ${ }^{6}$

Reviewing the Consumer Protection Law of UAE and the Draft Law 2013, it seems that both laws are not clear on the concept of misleading commercial advertising, whereby Draft Law 2013 stated that advertisements are misleading only when they put the consumer in the wrong, and this is the standard adopted by a majority of the Arab consumer protection laws. ${ }^{7}$

Moreover, the UAE Law makers ignored to state whether it would be possible to consider the omission or hiding of some data in the advertisement as a misleading act. On the other hand, British lawmakers do not miss this, and they stated clearly that intentional omission of standard information related to the advertised product or services is a form of deception. The British Law allowed to judge the question and decide the extent to which hidden information is essential or not. ${ }^{8}$

Section 6 in the Egyptian Consumer Protection Law (No. 76) of 2006) stated that every supplier and advertiser mostly provide consumers with the right information on the nature of the product and its features and avoid what may cause consumer to be misled on the true information on the product.

The Syrian Consumer Protection Law 2015 section 1 provides that advertisement is any way, aimed at promoting sale or marketing of a product or service, whether directly or indirectly readable or heard or visible or encoding. Added to that, the Syrian law had defined the misleading advertisement in a direct way. Section 1 provides that misleading advertisement is any advertisement that deals with a good, service, an offer or statement and includes false allegation or allegation formed in a way that will directly or indirectly deceive or mislead the consumer. The Syrian Consumer Protection Law is the only law among the Arab laws related to consumer protection that identifies misleading advertising directly.

\section{Conclusion}

In marketing strategy, advertising is a very important element, and advertising is in fact a potent tool greatly impacting the purchasing decision of consumers. Advertising familiarizes consumers with the product to consumers while promoting brand quality. Advertisement impacts the choice of consumer, and for this reason, advertisement needs to be fair and truthful. Aside from being unethical, misleading and false advertisements distort competition and consumer choice as well. Such advertisements violate some basic rights of consumers, including the right to information, the right to make a choice, and the right to be safeguarded against hazardous goods and services and against one-sided trade practices. ${ }^{9}$

\footnotetext{
${ }^{1}$ AlGhafri, Abdulla. "The inadequacy of consumer protection in the UAE: the need for reform." PhD diss., (2013).

${ }^{2}$ See Dubai Club Press, “Advertisement Revenue in the Arab World Reach $\$ 4.6$ Billion”, published in 17/04/2010. Available at: http://alrroya.com/node/69818.

${ }^{3}$ AlGhafri, Abdulla. "The inadequacy of consumer protection in the UAE: the need for reform." PhD diss., (2013).

${ }^{4}$ JCL 1976,s94.

${ }^{5}$ Khasawneh, Maha Youssef, and Hattab, Rasha Mohammed Tayseer. "Civil protection for the consumer of commercial advertising is misleading, according to the provisions of the Jordanian civil law and consumer protection Draft Law 2006", "University of Sharjah Journal of Shari'a and Law Sciences 9, no. 1 (2012): 163-186. (In Arabic)

${ }^{6}$ Rasha Hattab." Indeed, Legislative civil protection for the consumer of commercial advertising misleading": Study in the federal law on consumer protection and the draft Jordanian Consumer Protection Act. Sharjah,16 May (2016). https:/www.sharjah24.ae/ar/studies-andresearch/121593. (Accessed in February 2017).

${ }^{7}$ Ibid.

${ }^{8}$ Ibid.

${ }^{9}$ Pushpa Girimaji. "Misleading advertisement and consumer". "This Monograph is Published with the Financial Assistance from Department of Consumer Affairs. Ministry of Consumer Affairs, Food \& Public Distribution, Government of India" Indian Institute of Public Administration.(2013).
} 
As a form of communication, advertising is mean to draw the attention of consumers, and in today's business, it is an important element. Globalization and marketing have led to the flourishing of both advertisements and advertising agencies. In this regard, advertisement should be viewed as an important tool to expand the business and reach out to larger market of consumers. ${ }^{1}$

Notably, a misleading advertisement does not display true information of the advertised product, and one or more potentially misleading attributes may be included, for instance, wrong information, overstatement, deceptive price, and so forth. Such advertising misleads consumer in many ways. For instance, it may use ambiguous phrases that reader may misconstrue. Accordingly, consumer protection is stressed in Islamic teaching whereby all forms of misleading advertisement and deception in transaction are prohibited.

The points highlighted in this study imply the need for legislature intervention to achieve appropriate level of consumer protection, considering that the consumers are the weaker party from an economic standpoint. Also, consumers are viewed as less experienced and are not sufficiently educated legally.

\section{References}

Pushpa Girimaji. "Misleading advertisement and consumer". "This Monograph is published with the Financial Assistance from Department of Consumer Affairs. Ministry of Consumer Affairs, Food \& Public Distribution, Government of Indian" "institute of public administration. (2013)".

Siddiqui, Anjum. "Financial contracts, risk and performance of Islamic banking." "Managerial finance 34", no. 10 (2008): 680-694.

Al-Albani, M. Selselat Al ahadeith Al sahiha, 4th edition, Part 3, Al-Maktib Alislami. Hadith No. 1113. (1985).

Sahih Muslim, Book of Faith, Chapter: The Saying of the prophet (saws): "Whoever deceives us is not one of us." Hadith no. 102, "Dar Al-Kutub al-Ilmyah", Beirut, (2001).

Al-Shawkani, Ali Muhammad "Nabeel al Awtar Muntaqa al-Akhbar min Ahadeeth Saeed Al-Akhbar”, Dar alJameel, Beirut, P5, (1973).

Al-Salaheen, Abdul Majeed "Commercial Advertisements: Concept and Regulations in Islamic Fiqh", "Sharia and Law Journal”, Vol 21,(2004).(In Arabic)

Zahraa, Mahdi. "Unique Islamic law methodology and the validity of modern legal and social science research methods for Islamic research." "Arab law quarterly 18, no. 3 (2003): 215-249".

Alzaagy, Abdulrahman A. "Electronic Contract: A Study of Its Application in the Light of Islamic Law with Particular Reference to Saudi Arabia Case." "PhD diss., University of Wales, Aberystwyth”, (2009).

Asherman, Jeanne. "Doing Business in Saudi Arabia: The Contemporary Application of Islamic Law." "The International Lawyer", vol. 16, p. 321. (1982).

Hayajneh, Abdelnaser Zeyad. "Vanishing Borders: Can Human Rights be a subject of Private Law? Exploring Human Rights under Jordanian Civil Law." "European Journal of Social Sciences” (2011).

Hayajneh, Abdelnaser Zeyad. "Legal Surgery: The Need to Review Jordanian Civil Law.”," British Journal of Humanities and Social Sciences" (2012).

Alhusban, Ahmad. "The importance of consumer protection for the development of electronic commerce: the need for reform in Jordan." PhD diss., Doctoral dissertation, University of Portsmouth, (2014).

Majalla. Al-Majallah al-Ahkam al-Adaliyyah (The Majelle) - the Civil Law of the Ottoman Empire (Hanafi). Available at: http:/www.global-islamic-finance.com/2009/07/al-majallah-al-ahkam-aladaliyyah.html\#ixzz575wer3Rt (Accessed on July 2016).

Haider, Ali. "The Explanation Ottoman Courts Manual”. "Dar Ala'am Alkotb, Beirut, 1st, (2003)". 178 (in Arabic).

In Majah,” Book of Business Transactions", al-Maktab al-Islamy, Beirut, Hadith no. 2139, (1986).

Al-Manaseer, Ali Abdul Kareem Muhammad, "Commercial Advertisements: Concept and Ruling in Islamic Fiqh”, Dissertation, School of Legal Studies, Jordan University”, (2007).

Ahmad Shakir, "Advertisement", Dar Wael, Amman - Jordan,( 2003). In Arabic

Al-Salaheen, Abdul Majeed "Commercial Advertisements: Concept and Regulations in Islamic Fiqh", "Sharia and Law Journal", Vol 21, (2004). (In Arabic)

AlGhafri, Abdulla. "The inadequacy of consumer protection in the UAE: the need for reform." PhD diss., (2013).

Khasawneh, Maha Youssef, and Hattab, Rasha Mohammed Tayseer. "Civil protection for the consumer of commercial advertising is misleading, according to the provisions of the Jordanian civil law and consumer protection Draft Law 2006", "University of Sharjah Journal of Shari'a and Law Sciences 9, no. 1 (2012): 163-186. (In Arabic)

Rasha Hattab. "Indeed, Legislative civil protection for the consumer of commercial advertising misleading": Study in the federal law on consumer protection and the draft Jordanian Consumer Protection Act. Sharjah,16 May (2016). https://www.sharjah24.ae/ar/studies-and-research/121593. (Accessed in February 2017).

\footnotetext{
${ }^{1}$ Ramsay, Iain. Consumer law and policy: Text and materials on regulating consumer markets. Bloomsbury Publishing, (2012).
} 
Ramsay, Iain. Consumer law and policy: Text and materials on regulating consumer markets. Bloomsbury Publishing, (2012). 